\title{
Community-Based Interventions in the Field of Physical Activity for Rural Overweight and Obese Women in a Village In Iran
}

\author{
Maryam Baradaran Binazir ${ }^{1 *}$, Ramak Zavvarkabeh ${ }^{1}$, Ramin Mohammadzadeh ${ }^{2}$ and Fariba Heidari ${ }^{1}$ \\ ${ }^{1}$ Social Determinants of Health Research Center, Tabriz University of Medical Sciences, Iran \\ ${ }^{2}$ Student Research Committee and School of Pharmacy, Tabriz University of Medical Sciences, Iran
}

Submission: January 28, 2020; Published: February 11, 2021

*Corresponding author: Maryam Baradaran Binazir Social Determinants of Health Research Center, Tabriz University of Medical Sciences, Tabriz, Iran

\begin{abstract}
Abstrcat
One of the most important responsibilities of governments as a social institution is the strengthening of public health of the community and the creation of the necessary places for women's sports activities. This paper described the health effects of the Community-based interventions in the women's park of Saeidabad village, East Azarbaijan on province, Iran. In this cross-sectional study, 109 women participated. The statistical population of the study was selected from women over 30 years in Saeidabad who were sure to experience the community-centered design of women's park for physical activity. The participants mean age was 45.6 years. Most of them (98\%) had one or more risk factor for cardiovascular disease. Thirty people were diabetic and used insulin. They lowered insulin level. Thirty-five other had hyperlipidemia whose blood lipid levels were significantly decreased. Ten people had depression. These ten stopped taking the anti-depressive pills. The Body Mass Index (BMI) of 85 of the studied people was reduced. The development of a women-specific sport area for women has been shown to have positive physical, psychological and social effects on them, where they make use of amenities in a safe and low-cost environment, and their ease of use and satisfaction from national institutions.
\end{abstract}

Keywords: Women's park; Physical health; Social interaction; Women's sports

\section{Introduction}

As a significant behavior, physical activity is documented as a distinctive way to decrease whole burden of illnesses and health complications in human beings [1,2]. Cancer, cardiovascular disorders, diabetes, and chronic respiratory syndrome are reported as four main reasons of human death universally [3]. According to the WHO, women are often faced with the fact that they play an important role in family and community, through various physiological classes such as menstruation, pregnancy, childbirth [4]. According to reports, it seems that one of the most important causes of Iranian women's health is diabetes, high blood pressure, obesity and overweight that threaten their health [5]. Therefore, the importance of interventions to promote women's health is a scientific and practical necessity [6]. Research show differences between health care and the lack of access to health services during different lifetimes, as well as the impact of various personal, family and social roles, improving women's health in society and providing appropriate services [7]. One of the most important and effective interventions that can affect a large group of people is the use of community-based interventions that can be useful in promoting women's health through lifestyle changes. Basically, community-based and patient-centered interventions with emphasis on continuing education and patient support can significantly control blood sugar, increase quality of life and patient satisfaction from care and treatment [8]. In this regard, in a previous study, the effectiveness of communitybased intervention in improving physical activity for controlling overweight problem and obesity in a low-income society has been shown [9]. Another study found that community-based approaches were able to reduce the consumption of sugar beverages among young people and families, especially among high-risk families of obesity [10]. Considering that overweight and obesity, diabetes and high blood pressure in women were considered a significant threat, and on the other hand, the area of Saeidabad village of Tabriz was changing from rural to semiurban area, physical activity had been reduced among women, causing significant increase in obesity and overweight problems, diabetes, and blood pressure which have increased further visits of them in the health care centers. Therefore, one of the important needs of women in Saeidabad village was leisure and sports 


\section{Current Research in Diabetes \& Obesity Journal}

activities. Expression of demands with two goals of development of new recreational and sports facilities and promotion of current sports facilities named "Women's Park" was being pursued. It was Community-based interventions in the field of physical activity. So, in this study, the health effect of Community-based interventions in the field of physical activity for rural overweight and obese women in Saeidabad village had been evaluated regarding their participation in the Women's Park Project.

This research was a cross-sectional study thru individual semi-structured interviews, which was fulfilled in Saeidabad village, East Azarbaijan province, Iran from December 2018 to April 2019. The goal of the individual interviews was to recognize health effect of physical activity in women. Data were analyzed manually. The oral and written information about this study was for anyone with overweight/obesity. An informed and written informed consent form was collected for each participant who was not opposed to the study. This study was approved by the Ethics Committee of Tabriz University of Medical Sciences with an ethical approval number of IR.TBZMED.REC.1398.068.

The participants mean age was 45.6 years. Most of them (98\%) had one or more risk factor for cardiovascular disease. Twenty diabetic patients were taking oral pills. They lowered the number of pills. Also decreased hemoglobin A1c was seen on their blood analysis. Thirty people were diabetic and used insulin. They lowered insulin level. Thirty-five other had hyperlipidemia whose blood lipid levels were significantly decreased. Ten people had depression. These ten stopped taking the anti-depressive pills. The Body Mass Index of 85 of the studied people was reduced and forty-two were pre-diabetic whose fast blood sugar was reduced.

\section{Conclusion}

The community-based intervention had resulted in citizens' satisfaction from the municipality and sports institutions and their level of trust in the municipality had increased. The development of a women-specific sports area for women had been shown to have positive physical, psychological and social effects on them, where they made use of amenities in a safe and low-cost environment and their ease of use and satisfaction from national institutions.

\section{Acknowledgement}

We appreciate all rural women in Saeidabad village participated in this study.

\section{References}

1. (2009) Physical Activity Guidelines Advisory Committee report, 2008. To the Secretary of Health and Human Services. Part A: executive summary. Nutr Rev 67(2): 114-120.

2. Kankeu HT, Saksena P, Xu K, Evans DB (2013) The financial burden from non-communicable diseases in low- and middle-income countries: a literature review. Health Res Policy Syst 11: 31.

3. Bowen PG, Eaves YD, Vance DE, Moneyham LD (2015) A phenomenological study of obesity and physical activity in southern African American older women. J Aging Phys Act 23(2): 221-229.

4. Vlassoff C (2007) Gender differences in determinants and consequences of health and illness. J Health Popul Nutr 25(1): 47-61.

5. Ahranjani SA, Kashani H, Forouzanfar M, Meybodi HA, Larijani B, et al. (2012) Waist Circumference, Weight, and Body Mass Index of Iranians based on National Non-Communicable Disease Risk Factors Surveillance. Iran J Public Health 41(4): 35-45.

6. Jafari Adli S, Jouyandeh Z, Qorbani M, Soroush A, Larijani B, et al. (2014) Prevalence of obesity and overweight in adults and children in Iran; a systematic review. J Diabetes Metab Disord 13(1): 121.

7. Zavvarkabeh R, Mohammadzadeh R, Jabbari Bayrami H (2018) Association of Body Mass Index and Risk of Diabetes and Hypertension in the Rural Women Aged over 30 Years in Saeidabad, East Azarbayjan, Iran. Journal of Human, Environment, and Health Promotion 4(2): 9498.

8. Wang ML, Lemon SC, Clausen K, Whyte J, Rosal MC (2016) Design and methods for a community-based intervention to reduce sugarsweetened beverage consumption among youth: $\mathrm{H}_{2} \mathrm{GO}$ ! study. BMC public health 16(1): 1150.

9. Joulaei H, Maharlouei N, Lankarani KB, Razzaghi A, Akbari M (2016) Narrative review of women's health in Iran: challenges and successes. Int J Equity Health 15: 25-28.

10. Rahimi Foroushani A, Estebsari F, Mostafaei D, Eftekhar Ardebili H, Shojaeizadeh D, et al. (2014) The effect of health promoting intervention on healthy lifestyle and social support in elders: a clinical trial study. Iran Red Crescent Med J 16(8): e18399.

Your next submission with Juniper Publishers
will reach you the below assets
- Quality Editorial service
- Swift Peer Review
- Reprints availability
- E-prints Service
- Manuscript Podcast for convenient understanding
- Global attainment for your research
- Manuscript accessibility in different formats
( Pdf, E-pub, Full Text, Audio)
- Unceasing customer service
Track the below URL for one-step submission
https://juniperpublishers.com/online-submission.php

